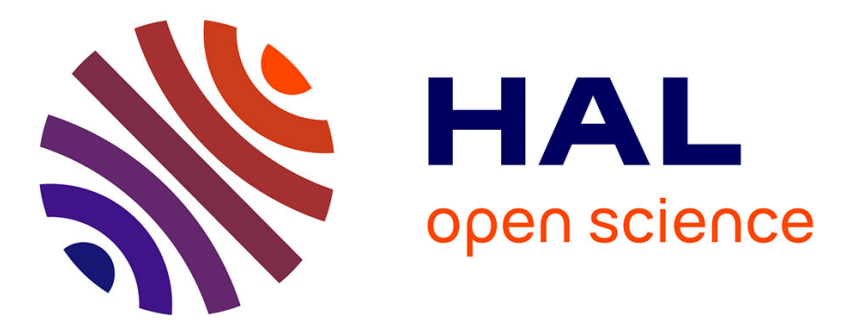

\title{
Differential responsiveness to oxytocin of the uterus and cervix in the ovariectomized ewe
}

\author{
Rafael Garcia Villar, P.L. Toutain, T. Ruckebusch, . Inra
}

\section{To cite this version:}

Rafael Garcia Villar, P.L. Toutain, T. Ruckebusch, . Inra. Differential responsiveness to oxytocin of the uterus and cervix in the ovariectomized ewe. Animal Reproduction Science, 1984, 7, pp.421-431. hal-02719082

\section{HAL Id: hal-02719082 \\ https://hal.inrae.fr/hal-02719082}

Submitted on 1 Jun 2020

HAL is a multi-disciplinary open access archive for the deposit and dissemination of scientific research documents, whether they are published or not. The documents may come from teaching and research institutions in France or abroad, or from public or private research centers.
L'archive ouverte pluridisciplinaire HAL, est destinée au dépôt et à la diffusion de documents scientifiques de niveau recherche, publiés ou non, émanant des établissements d'enseignement et de recherche français ou étrangers, des laboratoires publics ou privés.

\section{다(1)(2)}

Distributed under a Creative Commons Attribution - ShareAlikel 4.0 International 


\title{
DIFFERENTIAL RESPONSIVENESS TO OXYTOCIN OF THE UTERUS AND CER VIX IN THE OVARIECTOMIZED EWE
}

\section{R. GARCIA-VILLAR, P.L. TOUTAIN and Y. RUCKEBUSCH}

Institut National de la Recherche Agronomique, Station de Pharmacologie-Toxicologie, 180, chemin de Tournefeuille, 31300 Toulouse (France)

(Accepted 7 March 1984)

\begin{abstract}
Garcia-Villar, R., Toutain, P.L. and Ruckebusch, Y., 1984, Differential responsiveness to oxytocin of the uterus and cervix in the ovariectomized ewe. Anim. Reprod. Sci., 7: $421-431$.

The responsiveness of the uterus and cervix to oxytocin was compared in ovariectomized ewes fitted with intraparietal electrodes and treated with $17 \beta$-oestradiol. Before the injection of the steroid, only the cervix presented dose-related responses to oxytocin infusions. Within the 3-5-day period after oestrogen injection, both the uterus and cervix presented almost similar responsiveness to the neurohormonal agent. After the 6 th day following oestrogen, the cervix remained reactive to the infusions of oxytocin, whereas the uterus failed to respond. It is suggested that the reactivity of the cervix, which is at least partially independent of oestrogen priming, may be due to oestrogen-independent oxytocin receptors present only in the cervix.
\end{abstract}

\section{INTRODUCTION}

There have been many studies on the pharmacology of the uterus, but only a few of the cervix. However, these studies have shown that cervical tissue was able to respond to drugs in vitro or in vivo, with either contraction or relaxation (Fitzpatrick, 1956; Najak et al., 1970; Hollingsworth, 1974). Besides, studies have suggested differences in the sensitiveness to drugs between the cervix and the uterus (Newton, 1937; Adler et al., 1944; Fitzpatrick, 1957) but no definite statements, supported by experimental evidence, were presented.

The contractile response of the ovine uterus after administration of oxytocin is critically dependent upon the sex steroid status of the animal; during the last days of gestation, uterine responsiveness to oxytocin increases as parturition approaches (Hindson et al., 1969; Hindson and Ward, 1973) at times when an increase of plasma oestrogens and a decrease of plasma progesterone are observed (Liggins et al., 1973; Rawlings and Ward, 1976). Moreover, the number and affinity of oxytocin receptors in the membrane 
of myometrial smooth muscle cells, which would be the most relevant factors to be considered to explain the reactivity of the organ to the contractile agent, have been shown to be increased by oestrogens and decreased by progesterone (Soloff, 1975a; Nissenson, et al., 1978). In intact sheep, the concentration of high-affinity sites for oxytocin in the myometrium is highest during oestrus (Roberts et al., 1976), i.e. under oestradial priming. In a previous paper we have reported on the existence of an oestrogenindependent spontaneous activity in the cervix uteri, which remains active to some extent during the cyclic luteal phase, or after a bilateral ovariectomy, whilst the uterine horns display no activity (Garcia-Villar et al., 1982b). This suggested that the physiological regulation of spontaneous motility events by sex steroids would be different in these two locations. Fitzpatrick (1957) has observed that the cervix of the cow presents pressure responses to oxytocin in vitro and that the reactivity is far higher during oestrus than during the luteal phase or pregnancy, which suggests a permissive effect of oestrogen on the cervix as on other locations of the genital tract. Nevertheless, preliminary observations in post-partum ewes, from 3-4 days after lambing, have shown marked increases in cervical electrical activity at each suckling, suggesting that oxytocin is able to activate the cervix but not the horns in the absence of oestrogens. The aim of the present work was to compare the in vivo responsiveness of the uterus and the cervix to exogenous oxytocin in ovariectomized ewes, either in the absence of sex steroids or under $17 \beta$-oestradiol priming.

\section{MATERIAL AND METHODS}

Four adult ewes of the Lacaune breed, weighing between 45 and $56 \mathrm{~kg}$, were ovariectomized and fitted with intraparietal electrode wires under surgical conditions described in details in a previous paper (Garcia-Villar et al, 1982a). Electrodes were positioned on the ventral part of the uterine cervix and on both uterine horns. Recordings started 4 weeks after surgery: the animals, placed in individual cages, were continuously connected to the input panel of an 8-channel, direct writing amplifier (Minihuit, Alvar, France). Electromyograms (EMG) were integrated (Latour, 1973) and then analysed using a real time computer including a Motorola M6800 microprocessor, which allowed a quantitative assessment of spiking activity of both parts of the genital tract (Jourjon and Hachet, 1983, unpublished). The system collected the output part of the integrated signal simultaneously in the four ewes (three channels per ewe corresponding to cervix, right and left uterine horns). Return to baseline of the integrators was controlled by the computer. Genital tract activity was expressed in arbitrary computer units, one activity unit corresponding to one volt at the input of the integrator.

In order to test the reactivity to oxytocin (Syntocinon, Sandoz, France), 4 h-duration infusions via an indwelling jugular catheter using a Graseby Dynamics MS 16 pump were performed at the unique dose rate of 1 I.U. per 
h. The time schedule for the onset of infusions was $24 \mathrm{~h}$ before, and 24,48 , 72 and $144 \mathrm{~h}$ after, the intramuscular administration of $100 \mu \mathrm{g}$ of $17 \beta-$ oestradiol (Estradiol-17 $\beta$, Sigma, U.S.A.), in ethanol solution. Four complete series of infusions were performed in each ewe.

Dose-effect relationships were assessed only in the absence of oestradiol priming, i.e. after a minimum delay of 15 days (range 15-49 days) after the last administration of the sex steroid. Four dose rates were used: 0.1 , $0.3,1.0$ and 3.0 I.U, per $h$. Order of dose rates was randomly assigned and infusions of $2 \mathrm{~h}$-duration were performed via indwelling jugular catheters once per day, four times per ewe and per dose, unless otherwise indicated. Statistical analyses were performed by means of the Student's paired t-test, or analysis of variance and Newman-Keuls test.

\section{RESULTS}

\section{Responsiveness of the cervix and uterine horns to oxytocin infusions}

Activity pattern before oxytocin infusion. The electrical activity pattern recorded 4 weeks after ovariectomy, was similar in the 4 ewes, and corresponded to that described earlier (Garcia-Villar et al., 1982b). The uterine horns were almost silent and without recurring activity episodes. The cervix still presented activity episodes of 4 to 6 min duration, including a series of high amplitude $(300-500 \mu \mathrm{V})$ short spike bursts $(0.1 \mathrm{~s}$ duration) at a frequency of 4-10 per min. The frequency of occurrence of cervical activity episodes was variable from one animal to another, ranging from 0.35 to 0.92 per h.

A single intramuscular administration of $17 \beta$-oestradiol elicited spiking activity in the uterine horns after a delay of 6 to $10 \mathrm{~h}$. During this period the frequency of cervical activity episodes dropped dramatically. Thereafter, spiking activity increased in both parts of the genital tract. Maximal values were reached in all the animals within 18 to $23 \mathrm{~h}$ after oestradiol injection (Table I).

Activity pattern during oxytocin infusion. In the absence of oestradiol priming, the intravenous infusion of oxytocin significantly $(P<0.05)$ enhanced the level of activity of the uterine cervix (Fig. 1b). The EMG displayed periodical episodes of activity similar to those recorded during the control period, but during the whole course of the infusion, occurrence of these activity episodes was 3-4 times more frequent. This response was quickly abolished at the end of the $4 \mathrm{~h}$ of infusion. In contrast, no significant response was obtained, in any one of the ewes in any of the infusion series, at the level of the uterine horns $(P>0.05 ;$ N.S. $)$.

After oestrogen priming, the response of the cervix and the uterus to oxytocin infusion were almost parallel (Fig. 1a) for the infusions starting $24 \mathrm{~h}, 48 \mathrm{~h}$ and $72 \mathrm{~h}$ after oestradiol injection (Table II and Fig. 2). 


\section{TABLE I}

The effects of $17 \beta$-oestradiol priming on electrical activity (computer units per $h$ ) of the cervix and uterus of ovariectomized ewes. Values are mean \pm SD $(n=4)$, for each of the four oestrogen injections in each ewe. The periods considered corresponded to the $4 \mathrm{~h}$ that preceded each of the oxytocin infusions (see Table II)

\begin{tabular}{|c|c|c|c|c|c|c|}
\hline \multirow[b]{2}{*}{ Ewe no. } & \multirow[b]{2}{*}{ Location } & \multicolumn{5}{|c|}{ Electrical activity } \\
\hline & & $\begin{array}{l}\text { Control } \\
(-28 ;-24)^{\mathrm{a}}\end{array}$ & $(20 ; 21)$ & $(44 ; 48)$ & $(68 ; 72)$ & $(140 ; 144)$ \\
\hline \multirow[b]{2}{*}{1} & Cervix & $\begin{array}{r}67.50 \\
\pm 25.41\end{array}$ & $\begin{array}{l}654.50 \\
\pm 68.55\end{array}$ & $\begin{array}{l}456.00 \\
\pm 83.64\end{array}$ & $\begin{array}{l}430.50 \\
+62.26\end{array}$ & $\begin{array}{r}145,25 \\
+43,74\end{array}$ \\
\hline & Uterus & $\begin{array}{r}1.50 \\
\pm 2.38\end{array}$ & $\begin{array}{l}846.50 \\
\pm 72.13\end{array}$ & $\begin{array}{l}157.50 \\
\pm 60.64\end{array}$ & $\begin{array}{r}\mathbf{1 6 . 5 0} \\
\pm 13,02\end{array}$ & $\begin{array}{r}0.75 \\
\pm 0.96\end{array}$ \\
\hline \multirow{2}{*}{2} & Cervix & $\begin{array}{l}109.75 \\
\pm 16.21\end{array}$ & $\begin{array}{l}686.75 \\
\pm 72.13\end{array}$ & $\begin{array}{l}587.25 \\
\pm 57.86\end{array}$ & $\begin{array}{r}270.25 \\
+106.87\end{array}$ & $\begin{array}{l}123.25 \\
\pm 29.71\end{array}$ \\
\hline & Uterus & $\begin{array}{r}0.50 \\
\pm 1.00\end{array}$ & $\begin{array}{r}765.50 \\
\pm 313.56\end{array}$ & $\begin{array}{r}499.50 \\
\pm 157.78\end{array}$ & $\begin{array}{r}198.25 \\
\pm 130.82\end{array}$ & $\begin{array}{r}7.00 \\
\pm 14.54\end{array}$ \\
\hline \multirow{2}{*}{3} & Cervix & $\begin{array}{r}21.75 \\
\pm 13.30\end{array}$ & $\begin{array}{l}744.50 \\
\pm 38.14\end{array}$ & $\begin{array}{l}156.25 \\
\pm 20.05\end{array}$ & $\begin{array}{r}66.50 \\
\pm 24.47\end{array}$ & $\begin{array}{r}34.25 \\
\pm 16.15\end{array}$ \\
\hline & Uterus & $\begin{array}{r}0.50 \\
\pm 0.58\end{array}$ & $\begin{array}{l}787.75 \\
\pm 87.30\end{array}$ & $\begin{array}{l}489.25 \\
\pm 52.38\end{array}$ & $\begin{array}{l}43.75 \\
\pm 8.18\end{array}$ & $\begin{array}{r}6.50 \\
\pm 9.43\end{array}$ \\
\hline \multirow{2}{*}{4} & Cervix & $\begin{array}{r}52.25 \\
+24.90\end{array}$ & $\begin{array}{r}552.75 \\
\pm 144.93\end{array}$ & $\begin{array}{l}477.75 \\
\pm 99.86\end{array}$ & $\begin{array}{l}272.50 \\
\pm 47.04\end{array}$ & $\begin{array}{r}61.25 \\
\pm 24.60\end{array}$ \\
\hline & Uterus & $\begin{array}{r}8.00 \\
\pm 1.82\end{array}$ & $\begin{array}{r}690.50 \\
\pm 128.95\end{array}$ & $\begin{array}{r}399.25 \\
\pm 137.67\end{array}$ & $\begin{array}{r}268.50 \\
\pm 117.91\end{array}$ & $\begin{array}{r}81.25 \\
\pm 16.09\end{array}$ \\
\hline
\end{tabular}

${ }^{\text {a }}$ Hours according to $17 \beta$-oestradiol treatment.

Maximal values of electrical activity were reached within the infusion performed $24 \mathrm{~h}$ after oestradiol and this time grossly corresponded to the plateau of maximal oestrogen-induced activity on the two parts of the tract. Nevertheless, the ratio of increase above the actual basal levels preceding infusion periods remained high for the oxytocin infusion that started $48 \mathrm{~h}$ after oestradiol injection. At $72 \mathrm{~h}$ post-oestrogen, both parts of the genital tract remained reactive to oxytocin. Statistical analyses for pooled means for the four ewes are presented in Fig. 3.

In all the cases, 6 days after oestradiol administration, the cervix presented a significant response $(P<0.05)$ to the infusion of oxytocin. The uterine horns presented no response in $\mathbf{1 2}$ out of the 16 series of infusions and only light responses in the 4 other infusions. In these 4 cases return to control values for spontaneous activity (i.e. total quiescence) was not reached for the uterus. 


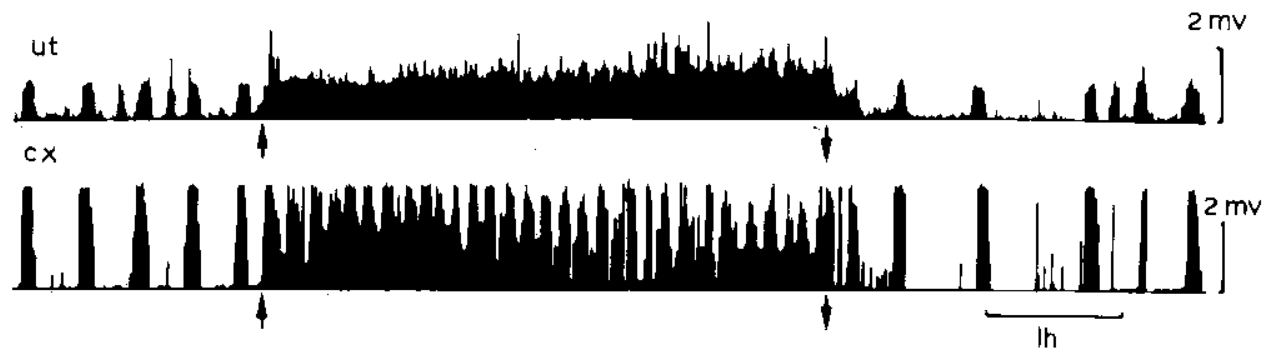

(b) without oestradiol

ut

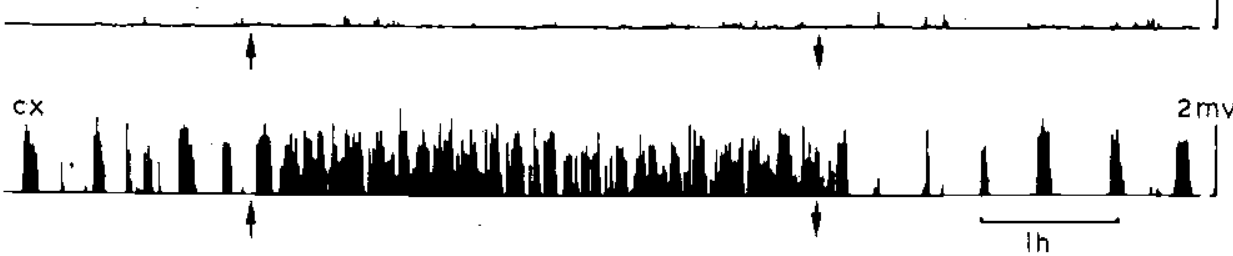

Fig. 1. Spontaneous and oxytocin-induced activity profiles of the uterine horn (ut) and cervix (cx) in the ovariectomized ewe. Under oestradiol priming, (a), both uterus and cervix displayed spontaneous and oxytocin-induced activities. Without oestradiol priming, (b), only the cervix presented both spontaneous and oxytocin-induced activity episodes. Note the enhancement of the occurrence of these episodes during the $4 \mathrm{~h}$ of oxytocin infusion (between arrows).

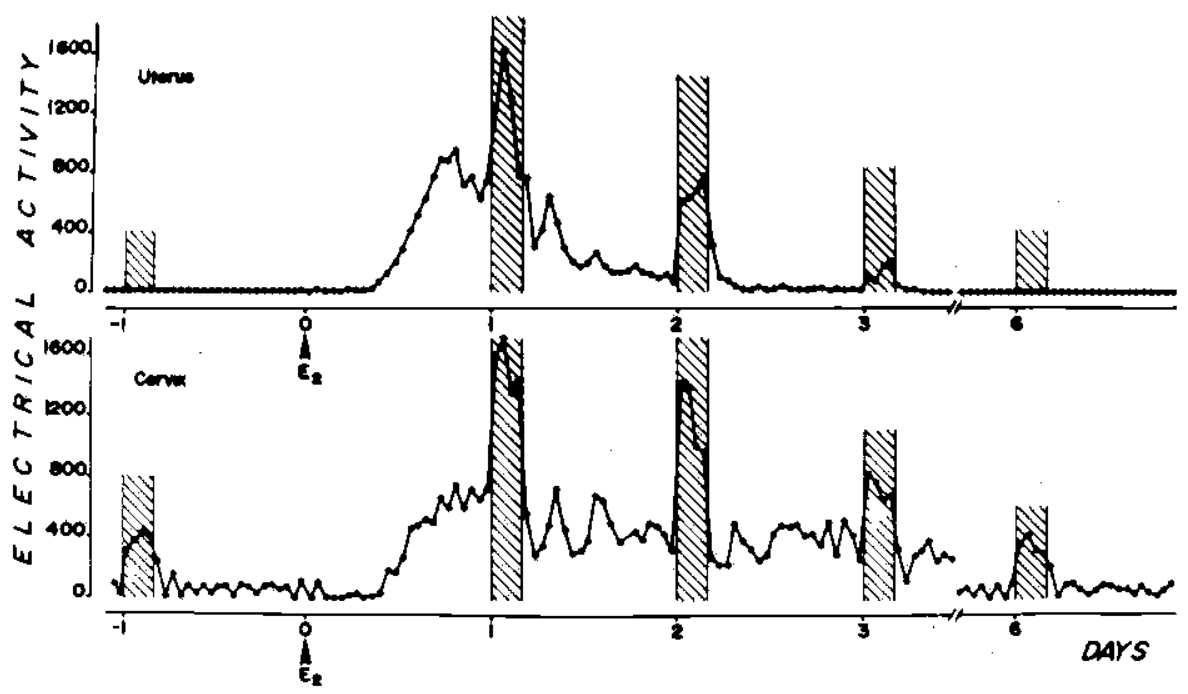

Fig. 2. Uterine and cervical electrical activity responses to a series of oxytocin infusions at a single rate of $1 \mathrm{I}$.U. per $\mathrm{h}$ during $4 \mathrm{~h}$ (hatched areas) before and after oestradiol $\left(\mathrm{E}_{2}\right)$ administration in one representative ewe. Electrical activity is expressed in arbitrary computer units per $h$. 
TABLE II

The effects of oxytocin infusions on electrical activity (computer units per h) of the cervix and uterus of ovariectomized ewes without (control) and under oestrogen priming. Values are mean \pm SD $(n=4)$ for 4 oxytocin infusions at a single dosage of 1 I.U. per $h$

\begin{tabular}{|c|c|c|c|c|c|c|}
\hline \multirow[b]{2}{*}{ Ewe no. } & \multirow[b]{2}{*}{ Location } & \multicolumn{4}{|c|}{ Electrical activity } & \multirow[b]{2}{*}{$(144 ; 148)$} \\
\hline & & $\begin{array}{l}\text { Control } \\
(-24 ;-20)^{\mathrm{a}}\end{array}$ & $(24 ; 28)$ & $(48 ; 52)$ & $(72 ; 76)$ & \\
\hline \multirow{4}{*}{1} & \multirow[t]{2}{*}{ Cervix } & $\begin{array}{r}256.50 \\
\pm 31.04\end{array}$ & $\begin{array}{r}1513.00 \\
+161.43\end{array}$ & $\begin{array}{r}1188.00 \\
+23974\end{array}$ & $\begin{array}{r}726.50 \\
+78.32\end{array}$ & 344.00 \\
\hline & & & & & & \\
\hline & \multirow{2}{*}{ Uterus } & 0.25 & 1216.00 & 696.25 & 131.25 & 0.50 \\
\hline & & \pm 0.50 & \pm 344.88 & $\pm 127,99$ & \pm 63.91 & \pm 0.57 \\
\hline \multirow{4}{*}{2} & \multirow{2}{*}{ Cervix } & 227,25 & 1530.00 & 1279.75 & 729.00 & 325.25 \\
\hline & & \pm 73.86 & \pm 168.44 & \pm 81.35 & \pm 182.07 & \pm 66.14 \\
\hline & \multirow{2}{*}{ Uterus } & 1.75 & 1777.25 & 1226.00 & 636.25 & 9.00 \\
\hline & & \pm 2.87 & \pm 114.52 & \pm 206.40 & \pm 58.72 & \pm 6.48 \\
\hline \multirow{4}{*}{3} & \multirow{2}{*}{ Cervix } & 104.00 & 1314.75 & 333.50 & 191.50 & 136.75 \\
\hline & & \pm 61.52 & \pm 233.00 & \pm 127.33 & \pm 60.49 & \pm 104.04 \\
\hline & \multirow{2}{*}{ Uterus } & 0.75 & 1510.50 & 1365.25 & 52.25 & 5.75 \\
\hline & & \pm 0.96 & \pm 345.52 & \pm 154.47 & \pm 34.85 & \pm 6.75 \\
\hline \multirow{4}{*}{4} & \multirow{2}{*}{ Cervix } & 302.25 & 1610.25 & 1209.00 & 616.50 & 411.50 \\
\hline & & \pm 61.55 & \pm 141.02 & $\pm 182,21$ & \pm 60.41 & \pm 70.26 \\
\hline & \multirow{2}{*}{ Uterus } & 16.75 & 1746.25 & 1611.00 & 749.25 & 86.50 \\
\hline & & \pm 9.17 & \pm 316.08 & \pm 226.29 & \pm 83.25 & \pm 49.83 \\
\hline
\end{tabular}

${ }^{a}$ Hours according to $17 \beta$-oestradiol treatment.

\section{Dose-effect relationships}

Increasing dosages of oxytocin elicited increasing responses of the uterine cervix in the animals deprived of oestradiol priming. Individual mean values are presented in Fig. 4. In two ewes only (nos. 3 and 4), at the four doses used, clear linear relationships were obtained between the activity response and the $\log$ of the dose. One ewe (no. 1) presented similar relationships in only three out of the four doses, despite the performance of a second series of four infusions at the highest dosage ( $3 \mathrm{I} . \mathrm{U}$. per $\mathrm{h}$ ). It was noteworthy that the pattern of activity was changed in this ewe for this dosage: the cervix presented an almost continuous activity of low amplitude which explained the drop in the global response. Another ewe (no. 2) had a low reactivity to oxytocin, with responses only slightly different until the highest dosage was reached. 
Pooled values for all the animals and all infusions showed linear log-doseeffect relationships for the cervix in the absence of oestrogen priming.

Even at high dosages, responses were not recorded at the level of the uterine horns in any animal or in any series of infusions in the absence of oestrogen priming.
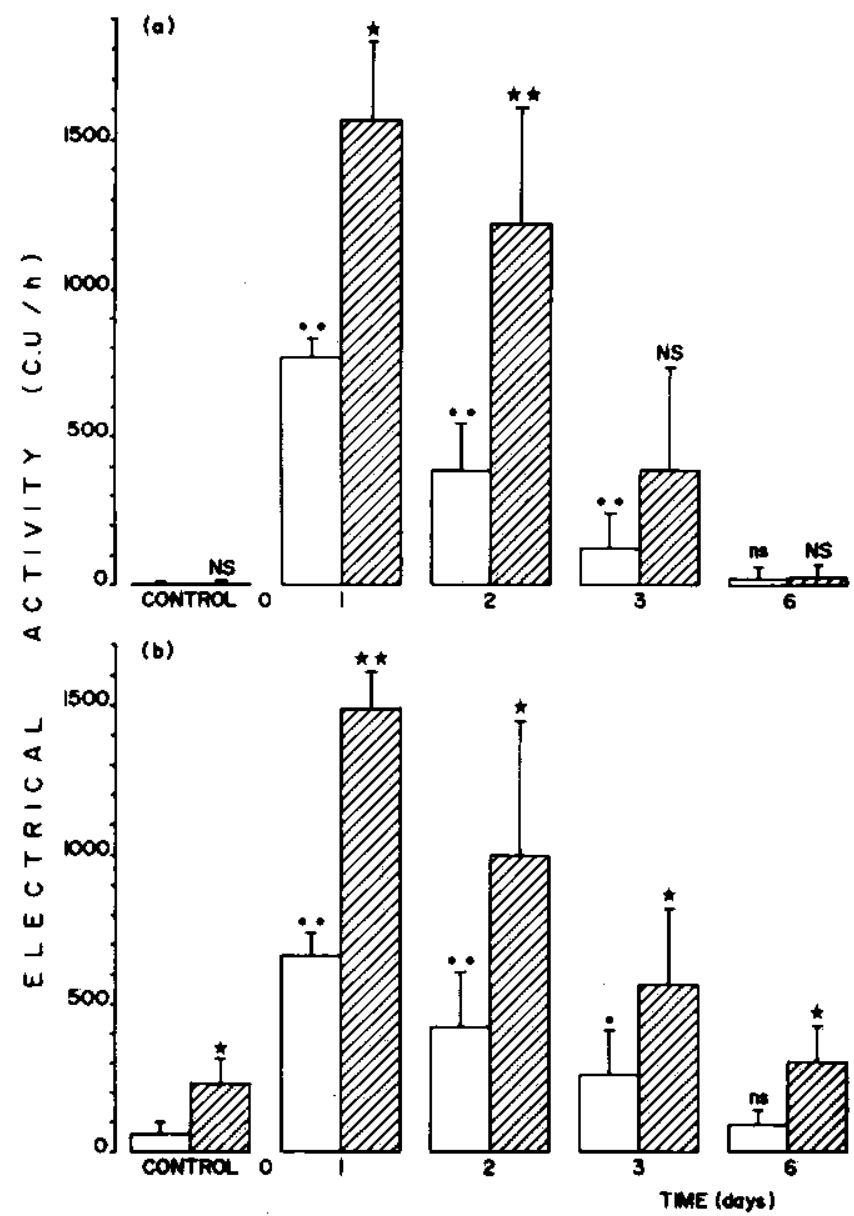

Fig. 3. Effects of a single intramuscular administration of 17/-oestradiol (open bars) and related responses to oxytocin infusions (hatched bars) upon uterus (a) and cervix (b). Values are mean $\pm \operatorname{SD}(n=4)$ pooled for the 4 ewes. Analysis of variance was performed to assess the effects of oestrogens, and comparisons among means were obtained from a Newman-Keuls test: $\log$ of each day-mean was considered in order to homogenize the variance amongst day-means $(\bullet P<0.05 ; \cdots P<0.01 ;$ n.s. not significant $)$. Statistical analysis of oxytocin response was made by Student's paired t-test between each control and related infusion periods $(\star P<0.05 ; \star \star P<0.01 ;$ NS not significant). 


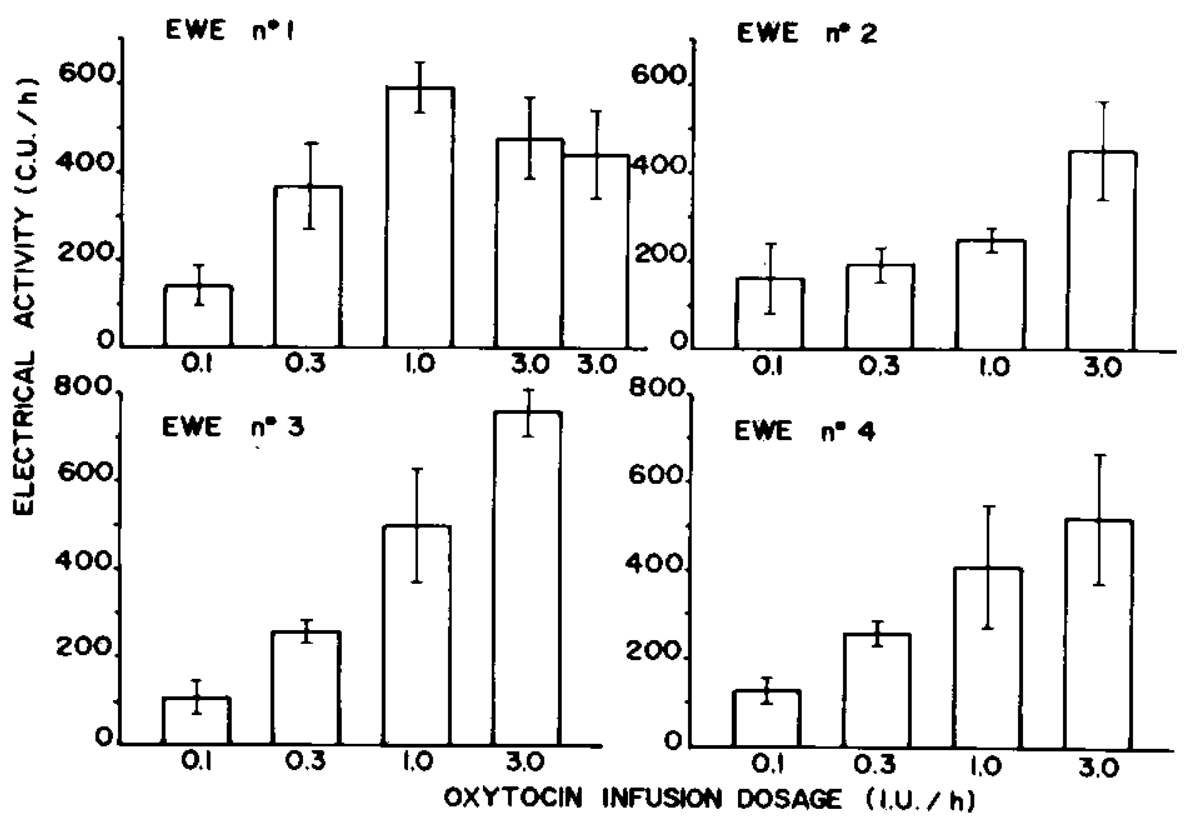

Fig. 4. Dose-effect relationships in the uterine cervix in the absence of oestradiol priming in 4 ewes. Each value is a mean $\pm \mathrm{SD}$ for 4 infusions per animal and per dose. Note that 4 additional infusions at the higher dosage have been performed in ewe no. 1 (C.U.: Computer Units; I.U.: International Units).

\section{DISCUSSION}

The present study clearly showed that the cervix and uterus respond to oxytocin after oestrogen treatment in the ovariectomized ewe. Without oestrogen priming, the cervix responds to oxytocin, the uterus does not.

As electromyography has been reported to be a valuable technique to assess motility of the cervix and uterus (Garcia-Villar et al., 1982a), drug effect upon both locations of the genital tract could be evaluated. Besides, a real time microcomputer was used to quantify the activity. In the ovariectomized ewe without oestrogen priming, oxytocin exhibited clear-cut, doseeffect relationships for the cervix, whilst the uterus remained totally quiescent even at high dosages. A mediation of these contractile effects, e.g. by prostaglandin $\mathrm{F}_{2 \alpha}\left(\mathrm{PGF}_{2 \alpha}\right)$ which is released locally after administration of oxytocin to ewes (Roberts and McCracken, 1976; Roberts et al., 1976), can be excluded from the present experiments, on the basis of two series of preliminary observations: (i) intravenous infusions of $\mathrm{PGF}_{2}$ analogs, known for their oxytocic potencies in the oestrogen-primed animal, failed to stimulate the motility of both uterus and cervix in the absence of oestrogen priming; (ii) cervical responsiveness to oxytocin still persisted in animals deprived of 
oestradiol and treated with indomethacin, an inhibitor of prostaglandin biosynthesis (personal observations). Such findings show a marked contrast with those for oxytocin, particularly at the level of the cervix.

Lack of uterine responsiveness to oxytocin in the absence of oestrogen priming is well known and is explained partly in terms of oxytocin receptors. Indeed, it is generally accepted that the first step for the contractile action of oxytocin on smooth muscle cells, e.g. of the oviducts (Soloff, 1975b), the uterus and the mammary gland (Soloff et al., 1977), consists in the binding of oxytocin to membrane high-affinity sites, namely oxytocin receptors, and that oestrogens act to increase the reactivity to oxytocin by increasing the number and affinity of these receptors (Soloff, 1975a; Nissenson et al., 1978). Although the presence of such receptors has not been demonstrated for the cervix, it is probable that, as for the above cited tissues, oxytocin receptors should exist at the cervix. If so, some hypotheses can be drawn from the present experiments.

After oestradiol priming, reactivity to oxytocin of the uterus and cervix followed an almost parallel development. This suggested that oestradiol, as for the uterus, increased the number and affinity of oxytocin receptors at the cervix level. However, in contrast to the uterus, the cervix kept its responsiveness to oxytocin in the absence of oestrogen priming. The fact that cervical responses were dose-related was compatible with an effect mediated via specific receptors, which could therefore be considered as oestrogen-independent receptors in contrast to the others which were oestrogen-dependent.

The existence of oxytocin receptors apparently independent of sex steroid regulation is not totally unexpected, as no obvious correlation existed between e.g. binding to mammary myoepithelial cells and plasma oestradiol or progesterone levels (Soloff, 1982). The biological significance of the existence of two kinds of oxytocin receptors remains unclear. Soloff (1982) pointed out that the dual type of regulation of uterine and mammary gland oxytocin receptors allowed oxytocin-induced uterine contractions without milk letdown during labour at term pregnancy and, conversely, uterine contractions remained minimal post-partum whilst oxytocin is released as a consequence of suckling. The eventual duality can hardly be explained in similar terms for the cervix. As physiological pulses of oxytocin released into the blood in the ewe during both the oestrous cycle and pregnancy (Mitchell et al., 1982) remained inefficient to induce related contractions of the genital tract (Garcia-Villar et al., 1983), the only specific conditions under which an increase in blood oxytocin would be able to stimulate the cervix but not the uterus would probably be suckling and accidental vaginal distension in the non-oestrous ewe. Under these two conditions, one may suppose that oxytocin-induced contraction would allow the cervix to assume a "house-keeper" function. 


\section{ACKNOWLEDGEMENTS}

The authors would like to thank Messrs M. Caussette and D. Tardieu for technical help, Mrs C. Soual and Mr J.P. Soula for animal care.

\section{REFERENCES}

Adler, J., Bell, G.H. and Knox, J.A.C., 1944, The behaviour of the cervix uteri in-vivo. J. Physiol. (Lond.), 75: 142-154.

Fitzpatrick, R.J., 1956. On oxytocin and uterine function. The Colton Papers, $7: 203-$ 219.

Fitzpatrick, R.J., 1957. The activity of the uterine cervix in ruminants. Vet. Rec., 69; $713-717$.

Garcia-Villar, R., Toutain, P.L. and Ruckebusch, Y., 1982a. Electromyographic evaluation of the spontaneous and drug-induced motility of the cervix in sheep. J. Pharmacol. Methods, $7:$ :83-90.

Garcia-Villar, R., Toutain, P.L., Moré, J. and Ruckebusch, Y., 1982b. Spontaneous motility of the cervix in cycling and ovariectomized ewes and changes induced by exogenous hormones. J. Reprod. Fertil., 66: 317-326.

Garcia-Villar, R., Toutain, P.L., Schams, D. and Ruckebusch, Y., 1983. Are regular activity episodes of the genital tract controlled by pulsatile releases of oxytocin? Biol. Reprod., 29: 1183-1188.

Hindson, J.C. and Ward, W.R., 1973. Myometrial studies in the pregnant sheep. In: C.G. Pierrepoint (Editor), The Endocrinology of Pregnancy and Parturition. Experimental Studies in the Sheep. Alpha-Omega-Alpha Publishers, Cardiff, pp. 153-173.

Hindson, J.C., Schoffield, B.M. and Ward, W.R., 1969. The effect of progesterone on recorded parturition and on oxytocin sensitivity in the sheep. J. Endocrinol., 43: 207-215.

Hollingsworth, M., 1974. The innervation of the rat cervix and its pharmacology in vitro and in vivo. Br. J. Pharmacol., 52: 539-547.

Latoux, A., 1973. Un dispositif simple d'analyse quantitative de l'électromyogramme intestinal chronique. Ann. Rech. Vet., 4: 347-353.

Liggins, G.C., Fairclough, R.J., Grieves, S.A., Kendall, J.Z. and Knox, B.S., 1973, The mechanism of initiation of parturition in the ewe. Recent. Prog. Horm. Res., 29: 111159.

Mitchell, M.D., Kraemer, D.L., Brennecke, S.P., and Webb, R., 1982. Pulsatile release of oxytocin during the oestrous cycle, pregnancy and parturition in sheep. Biol. Reprod., 27: 1169-1173.

Najak, Z., Hillier, K., and Karim, S.M.M., 1970. The action of prostaglandins on the human isolated, non-pregnant cervix. J. Obstet. Gynecol. Br, Commonw., 78: 716723.

Newton, W.H., 1937. The insensitivity of the cervix uteri to oxytocin. J. Physiol. (London) $89: 309-315$.

Nissenson, R., Flouret, G. and Hechter, O., 1978. Opposing effects of oestradiol and progesterone on oxytocin receptors in rabbit uterus. Proc. Natl. Acad. Sci. U.S.A., 75 : $2044-2048$.

Rawlings, N.C. and Ward, W.R., 1976. Changes in steroid hormones in plasma and myometrium and uterine activity in ewes during late pregnancy and parturition. J. Reprod. Fertil., 48: 355-360.

Roberts, J.S, and McCracken, J.A., 1976. Does prostaglandin $F_{2 \alpha}$ released from the uterus by oxytocin mediate the oxytocic action of oxytocin? Biol. Reprod., 15: 457-463. 
Roberts, J.S., McCracken, J.A., Gavagan, J.E. and Soloff, M.S., 1976. Oxytocin-stimulated release of prostaglandin $F_{2 \alpha}$ from ovine endometrium in vitro: correlation with estrous cycle and oxytocin-receptor binding. Endocrinology, 99: 1107-1114.

Soloff, M.S., 1975a. Uterine receptor for oxytocin: effects of estrogen. Biochem. Biophys. Res. Commun., 65: 205-212.

Soloff, M.S., 1975b. Oxytocin receptor in rat oviduct. Biochem. Biophys. Res. Commun., 66: $671-677$.

Soloff, M.S., 1982. Oxytocin receptor and mammary myoepithelial cells. J. Dairy Sci., 65: $326-337$.

Soloff, M.S., Schroeder, B.T., Chakraborty, J. and Pearlmutter, A.F., 1977. Characterization of oxytocin receptors in the uterus and mammary gland. Fed. Proc., 36: 18611866. 
$\therefore$ 